\title{
Optimisation of orientation for large underground caverns
}

\author{
Hari Dev \\ Central Soil and Materials Research Station \\ New Delhi, India \\ Haridev65@gmail.com
}

\author{
Rajbal Singh and SK Sati \\ WAPCOS Ltd. \\ Gurgaon, India \\ Rajbal.singh@nic.in
}

\begin{abstract}
This paper highlights the role of stress measurements and wedge analysis for optimisation of orientation for underground desilting chambers and power house complex of hydropower development in the Himalayas. In-situ stress measurement tests were conducted using hydraulic fracturing technique in vertical and horizontal holes. Wedge analysis of the existing joint sets was also done to study the potential wedge failure and to optimize the orientation of underground caverns. The orientations of joint sets at outcrop were different than inside the cavern due to folding and faulting in rock mass. The final decision on orientation of large underground caverns was optimised based on in-situ stress measurements and analysis of existing joint sets inside the cavern.
\end{abstract}

Keywords-hydrofracturing, wedge analysis, stereo plotting, isotropic stress theory

\section{INTRODUCTION}

Hydropower development envisages construction of large underground facilities such as desilting chambers, power house, transformer hall, upstream/downstream surge chambers etc. Design and construction of underground caverns largely depend on the prevailing in-situ and induced stresses. In-situ stress is a vital parameter which affects the stability of underground openings inside rock mass. Most types of failures in rock are related to the prevailing in-situ stress. The stress field existing in a rock mass is always a result of many processes and mechanisms. It is of particular importance in rock engineering, since the stress field defines the boundary conditions for underground modelling and designs. Primary source of stress around any underground opening is weight of the overlying rock cover. Determination of in-situ state of stress in a rock mass is equivalent to the determination of the tectonic and gravitational stress.

Heim [1] in his hydrostatic stress field theory stated that rocks in earth's crust are in a state of hydrostatic stress equilibrium similar to those in liquids. The theory was later on modified to litho-static stress field theory assuming that rocks in the crust are in isotropic state which means:

$$
\sigma_{\mathrm{H}}=\sigma_{\mathrm{h}}=\sigma_{\mathrm{v}}=\mathrm{P}_{\mathrm{c}}
$$

where $\sigma_{\mathrm{H}}$ and $\sigma_{\mathrm{h}}$ are maximum and minimum components of horizontal stress, $\sigma_{v}$ is the vertical stress and $P_{c}$ is the confining pressure.
In the absence of any stress measuring technique available at that time, the theory was used in design of underground structures. Though vertical stresses may be estimated based on overburden, but it is difficult to estimate the horizontal stresses. Terzaghi and Richart [2] replaced litho-static stress field theory by uniaxial strain model which suggests that rocks being confined at depth, the horizontal expansion is restricted by adjacent rock, so that ideally principal strains $\varepsilon_{1} \neq 0, \varepsilon_{2}=\varepsilon_{3}=0$, thus making the horizontal stress a function of the weight of the overburden and the Poisson's ratio only. The stress ratio $\sigma_{H} / \sigma_{\mathrm{V}}$ is denoted by the letter k:

$$
\sigma_{\mathrm{H}}=\sigma_{\mathrm{h}}=\rho \mathrm{gZ}[\mathrm{v} /(1-\mathrm{v})]=\mathrm{k} \sigma_{\mathrm{v}}
$$

Where $\rho$ is the integrated rock density of the overburden, $\mathrm{g}$ is the gravitational acceleration, $v$ is the Poisson's ratio, $\mathrm{Z}$ is the depth at the point of interest, $\sigma_{\mathrm{v}}$ is the vertical stress and $\mathrm{k}=\mathrm{v} /(1-\mathrm{v})$.

This equation suggests that major principal stress is vertical stress as illustrated below:

if $v=0.25$, the stresses in horizontal direction derived from equation (2) are as follows:

$$
\sigma_{\mathrm{H}}=\sigma_{\mathrm{h}}=0.33 \sigma_{\mathrm{v}}
$$

It was noticed that horizontal stresses frequently exceeded the vertical overburden pressure. Wegener ${ }^{[3]}(1915)$ in his continental drift hypothesis connected all orogenic and tectonic events with large horizontal movements in the earth crust. Hast [4] found that horizontal stresses often exceeds by 1.3 to 1.5 times the vertical stress and in extreme cases it goes upto 8 times. Dewey [5], Mckenzie and Sclater [6] Courtillot and Vink [7] further corroborated and verified the plate tectonics hypothesis by contributing substantial evidence about the driving forces between continents. Actual measurements of stresses suggested that ' $\mathrm{k}$ ' is very high at shallow depth and it decreases with depth Brown and Hoek [8], Herget [9] while conducting stress measurements very close to surface, Zoback [10] observed marked changes in stress orientations and their magnitudes which may be related to effects of nearby topography or a high degree of near surface fracturing.

Failure in underground openings in jointed rock masses at relatively shallow depth is structurally controlled which 
involve wedge formations by intersecting structural features. Structurally controlled instabilities are generally driven by a unidirectional body force i.e. gravity. Hoek [11] and Croney [12] et al. analysed the structurally controlled failure mechanisms and design of associated supports. Stress controlled failures occur at greater depth where high stresses are occurring and the rock mass is relatively homogeneous and isotropic. Elesto-plastic thermal stress model of earth by Sheorey [13] considers curvature of the crust and variation of elastic constants, density and thermal expansion coefficients through the crust and mantle.

\section{CRITERIA For ORIENTATION OF UNDERGROUND CAVERNS}

In-situ stress is one of the major input parameters for deciding the size, shape and orientation of tunnels and underground caverns. Generally, the favourable orientation of the underground cavern is considered as direction of maximum horizontal stress so as to avoid unnecessary wall pressures during excavation and to ensure stability of the structure. High wall pressures may cause excessive convergences leading to instability. To minimise possibilities of potential wedges, long axis of the cavern may be aligned perpendicular to the strike of bedding plane. Stability of the underground structure against formation of wedges resulting from the intersection of joints and other discontinuities should be ensured. However, topography and other geological aspects cannot be ruled out while deciding the orientation. In jointed media, wedge analysis becomes more significant which requires mapping and stereo plotting of all the major joint sets. After stereonet plotting of all the joints, the suitable orientation can be worked out based on minimum potential wedges. Though, tentative orientation of the cavern may be worked out on the basis of joint sets seen as outcrop, but it is essential to review the design as excavation progresses right into the actual rock mass.

In certain situations, both the above criteria may suggest obtuse orientations or even perpendicular to each other also. If there seems to be a conflict between optimal orientation against principal stress direction and joint set orientation, then each individual case must be decided on relative importance of the two parameters. Suitable orientation of underground caverns is decided based upon the in-situ stresses and wedge analysis of major joint sets [14].

In the event of high in-situ stresses and large rock covers, where rock burst conditions may be anticipated, principal stress direction should be preferred for deciding the orientation. However, if there are no stress induced risks like rock burst and squeezing then wedge failure stability will be critical. Topography of the hill i.e. whether steep slope or isolated ridge, too plays a significant role in optimization of cavern orientation.

\section{GEOLOGY}

\section{A. Desilting chambers}

Four desilting chambers of 1020 MW Punatsangchhu-II hydroelectric project in Bhutan are located at right bank hill slope with steep cliff and escarpments. The hill slope rises continuously from river at EL $760 \mathrm{~m}$ and to more than EL $1400 \mathrm{~m}$ with $50^{0}-85^{0}$ slope. The proposed desilting chambers have a lateral cover of $200 \mathrm{~m}$ to $250 \mathrm{~m}$ and vertical cover of $150 \mathrm{~m}$ to more than $400 \mathrm{~m}$. The rock exposed in the area is mainly quartzo-gneisses, biotite gneisses and leucogranite belonging to sure formation of Thimpu group, occasionally intruded by pegmatite. The foliation is widely varying and the general strike of foliation is $\mathrm{N} 60^{\circ} \mathrm{E}$ to $\mathrm{N} 80^{\circ} \mathrm{W}-\mathrm{S} 60^{\circ} \mathrm{E}$ to $\mathrm{S} 80^{\circ} \mathrm{W}$ with $10^{\circ}-30^{\circ}$ dipping towards SE.

In the excavated portion of adit to desilting chambers, the rock type encountered is quartzo-feldspathic, biotite gneisses with intrusion of pegmatite veins. At some places dripping was also observed. Poor to fair rock mass was encountered during the excavation of adit to desilting chambers with $\mathrm{Q}$ values ranging from 2.7 to 9.0 .

\section{B. Power house and downstream surge chambers}

Proposed underground power house complex lies on the left abutment of the Kamechu nala, a right bank tributary of Punatsangchhu River, about $4 \mathrm{~km}$ upstream of the Pinsa location. In this area, biotite gneiss with intrusions of leucogranite and pegmatite are exposed. Leucogranite exposures are present in the Kamechu nala section.

Both the northern and southern slopes of this hill are characterized by steep gradient and show scarp/cliff sections with the remaining area covered with moderately steep slope under a cover of overburden soil. On both the slopes, limited outcrop of rocks are visible. Two major rock types i.e. biotite gneiss and leucocratic granite constitute the hills. Leucocratic granitoid is medium to coarse grained, hard and compact when fresh and forms steep scarp faces. On the northern slope face, leucogranite is occurring with the biotite gneiss bands while on the southern slope face of the power house hill, the occurrence of leucogranite bodies is more.

\section{StRESS MEASUREMENTS By HYDRAULIC FRACTURING TEST}

Hydraulic fracturing test is one of the methods used for measurement of in-situ stress in rock. The test is conducted with a robust double packer system called straddle packers on short borehole intervals which are free of natural fractures [15]. Fundamental principle underlying the application of hydraulic fracturing is that:

i) one of the principal stress components is co axial with the test hole.

ii) the long term shut-in pressure is approximated as the magnitude of the smaller horizontal stress component.

iii) the crack will generally tend to initiate in a plane normal to minimum stress (i.e. along the maximum stress).

Hydraulic fracturing method essentially consists of:

a) drilling of suitable diameter boreholes,

b) selecting test locations after inspecting the drillhole rock cores, 
c) isolating the test section with the help of inflatable rubber packers,

d) pressurising test section hydraulically to obtain an artificial fracture in rock followed by a number of repressurisation cycles till constant reopening pressure is obtained,

e) obtaining a pressure time record,

f) obtaining the impression of the induced crack on an semicured rubber wrapped onto the impression tool, and

g) interpretation of magnitude and orientation of stresses.

\section{A. Stresses in Underground Caverns}

In-situ stress measurement tests were carried out in the desilting chamber drift and downstream surge chamber adit using hydraulic fracturing technique. Tests were carried out in vertical drillhole for measuring the magnitude and direction of horizontal stresses (ISRM[16], 1981). Similarly, tests in horizontal drillhole were performed to measure the magnitude of vertical stress which otherwise may be estimated from depth of overlying rock mass which otherwise can roughly be estimated as $1.0 \mathrm{MPa}$ per $40 \mathrm{~m}$ depth of rock mass/overburden. In the present case, both horizontal stresses as well as vertical stress were measured by hydraulic fracturing test.

The cores obtained from the drillholes showed RQD and core recovery particularly those obtained from vertical drillhole which means the number of ideal locations for conducting the hydraulic fracturing tests were limited. However, observing the rock cores precisely, mechanical breakage of cores was also noticed apart from the joints. Hence, test locations were decided by applying own judgement and experience. In the absence of $100 \%$ core recovery, the task of deciding the test locations became very tough. However, by trial and error, sufficient tests could be conducted.

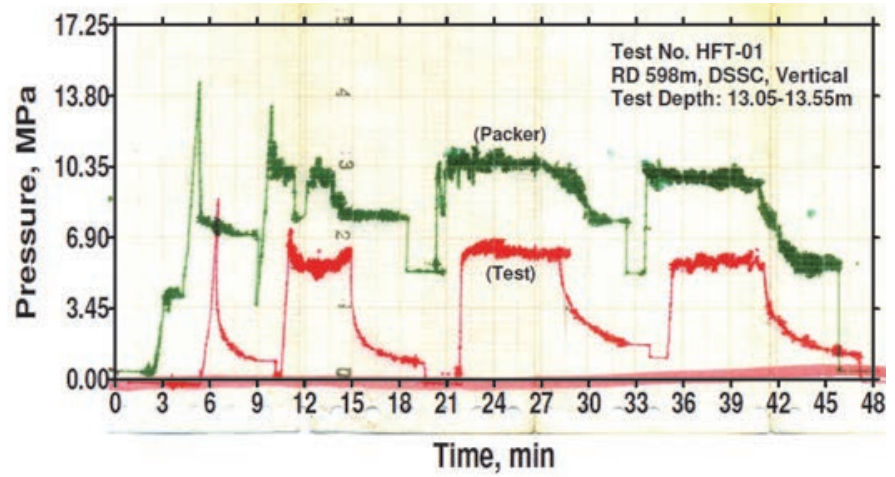

Fig.1. Pressure time record of one of the tests

Hydraulic fracturing tests were carried out in adit to desilting chamber and adit to downstream surge chamber in power house complex for the determination of in-situ stresses. Pressure-time record and impression of the induced crack for one of the tests are shown in Fig. 1, and 2, respectively.

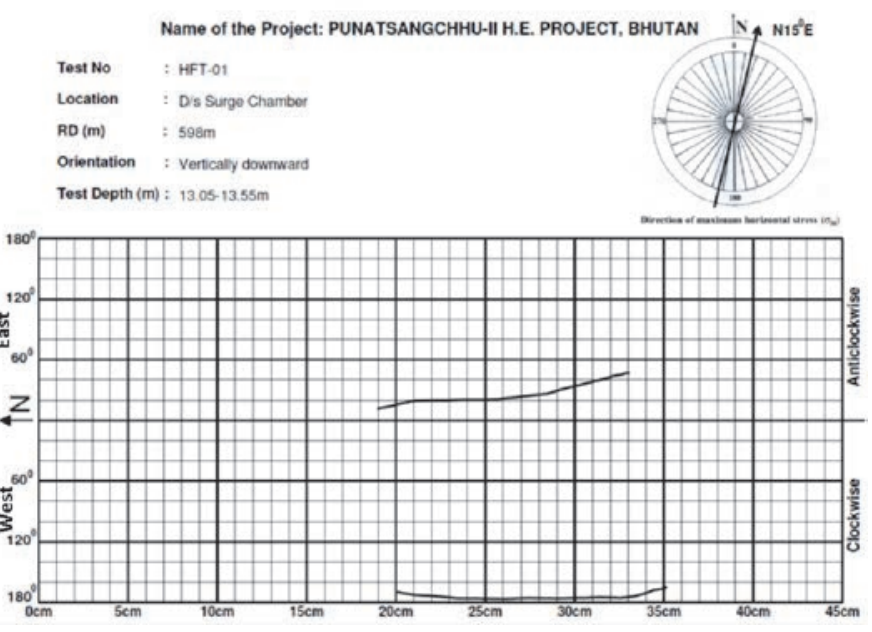

Fig 2. Impression record of induced crack from one of the tests

The average values of in-situ stresses determined in the desilting chambers and power house complex (downstream surge chambers) on the basis of tests carried out in vertical and horizontal drillholes are presented in Table I (CSMRS[17] 2012, CSMRS [18] 2013).

TABLE I. IN-Situ StResSes IN Desilting Chambers AND POWER HOUSE COMPLEX.

\begin{tabular}{|l|l|l|}
\hline Item & $\begin{array}{l}\text { Desilting } \\
\text { chambers }\end{array}$ & $\begin{array}{l}\text { Power house } / \\
\text { downstream } \\
\text { surge chambers }\end{array}$ \\
\hline $\begin{array}{l}\text { Maximum horizontal } \\
\text { stress, } \sigma_{\mathrm{H}},(\mathrm{MPa})\end{array}$ & 6.52 & 4.02 \\
\hline $\begin{array}{l}\text { Minimum horizontal } \\
\text { stress, } \sigma_{\mathrm{h}},(\mathrm{MPa})\end{array}$ & 5.02 & 2.99 \\
\hline $\begin{array}{l}\text { Measured vertical stress, } \\
\sigma_{\mathrm{v}(\text { Measured })},(\mathrm{MPa})\end{array}$ & 4.28 & 4.14 \\
\hline $\begin{array}{l}\text { Estimated vertical stress, } \\
\sigma_{\mathrm{v}(\text { Estimated })}(\mathrm{MPa})\end{array}$ & 4.64 & 5.17 \\
\hline Ratio of $\sigma_{\mathrm{H} / \sigma_{\mathrm{v}(\text { Measured })}}$ & 1.52 & 0.97 \\
\hline Ratio of $\sigma_{\mathrm{h} /} \sigma_{\mathrm{v}(\text { Measured })}$ & 1.17 & 0.78 \\
\hline $\begin{array}{l}\text { Orientation of maximum } \\
\text { horizontal stress }\end{array}$ & $\mathrm{N} 49^{0} \mathrm{~W}$ & $\mathrm{~N} 17^{0} \mathrm{E}$ \\
\hline
\end{tabular}

\section{WEDGE ANALYSIS}

\section{A. Desilting Chambers}

Wedge analysis considering all the major joint sets in the desilting chambers area was done. For this, joint sets data from exploratory drift and subsequently adit to desilting chamber were logged (Table II) and stereo plotted to obtain favourable direction of the underground desilting chambers (Fig. 3).

The vulnerable wedges likely to be formed by the intersection of the joint sets on the wall as well as on the crown of the chamber have been tentatively delineated assuming friction angle $(\varphi)$ of the rock joints as $30^{\circ}$ (Table III). 
Wedge analysis of joint sets indicated the most favourable orientation of desilting chambers as $\mathrm{N} 50^{\circ} \mathrm{W}$. Stress measurements suggested the favourable orientation of underground desilting chambers as $\mathrm{N} 49^{\circ} \mathrm{W}$.

TABLE II. DETAILS OF JOINT SETS IN DESILTING CHAMBERS

\begin{tabular}{|c|c|c|c|c|c|c|}
\hline $\begin{array}{l}\text { Join } \\
\text { set }\end{array}$ & $\begin{array}{l}\text { Strike } \\
\text { direction }\end{array}$ & $\begin{array}{l}\text { Dip } \\
\text { amount }\end{array}$ & $\begin{array}{l}\text { Dip } \\
\text { direction }\end{array}$ & Spacing & $\begin{array}{l}\text { Contin- } \\
\text { uity }\end{array}$ & Opening \\
\hline 1. & $\begin{array}{l}\mathrm{N} 70^{0} \mathrm{E}- \\
\mathrm{S} 70^{\circ} \mathrm{W}\end{array}$ & $20^{0}$ & SE & $0.5-1 \mathrm{~m}$ & $5-10 \mathrm{~m}$ & $\begin{array}{l}\text { Tight to } \\
2 \mathrm{~mm}\end{array}$ \\
\hline 2. & $\begin{array}{l}\mathrm{N} 15^{0} \mathrm{~W}- \\
\mathrm{S} 15^{\circ} \mathrm{E}\end{array}$ & $50^{\circ}$ & $\mathrm{NE}$ & $1-10 \mathrm{~m}$ & $2-20 \mathrm{~m}$ & $\begin{array}{l}\text { Tight to } \\
2 \mathrm{~mm}\end{array}$ \\
\hline 3. & $\begin{array}{l}\mathrm{N} 60^{\circ} \mathrm{E}- \\
\mathrm{S} 60^{\circ} \mathrm{W}\end{array}$ & $80^{0}$ & $\mathrm{SE}$ & $1-10 \mathrm{~m}$ & $2-20 \mathrm{~m}$ & $2-5 \mathrm{~mm}$ \\
\hline 4. & N-S & $50^{\circ}$ & East & $0.3-2 \mathrm{~m}$ & $2-5 \mathrm{~m}$ & $5-10 \mathrm{~mm}$ \\
\hline 5. & $\begin{array}{l}\mathrm{N} 80^{\circ} \mathrm{E}- \\
\mathrm{S} 80^{\circ} \mathrm{W}\end{array}$ & $80^{\circ}$ & NW & $1-5 \mathrm{~m}$ & $3-10 \mathrm{~m}$ & $2-5 \mathrm{~mm}$ \\
\hline 6. & $\begin{array}{l}\mathrm{N} 70^{\circ} \mathrm{W}- \\
\mathrm{S} 70^{\circ} \mathrm{E}\end{array}$ & $80^{\circ}$ & SW & $0.3-5 \mathrm{~m}$ & $2-5 \mathrm{~m}$ & $\begin{array}{l}\text { Tight to } \\
2 \mathrm{~mm}\end{array}$ \\
\hline
\end{tabular}

TABLE III. VULNERABLE WEDGES IN DESILTING CHAMBERS

\begin{tabular}{|c|c|c|c|}
\hline $\begin{array}{l}\text { Line of } \\
\text { intersection }\end{array}$ & $\begin{array}{l}\text { Plunge } \\
\text { amount }\end{array}$ & $\begin{array}{l}\text { Plunge } \\
\text { direction }\end{array}$ & Remarks \\
\hline $\mathrm{I} 1(\mathrm{~J} 2 \Lambda \mathrm{J} 3)$ & $48^{0}$ & $\mathrm{~N} 80^{\circ} \mathrm{E}$ & $\begin{array}{l}\text { Possible wedge on } \\
\text { the crown and left } \\
\text { wall }\end{array}$ \\
\hline $\mathrm{I} 2(\mathrm{~J} 2 \wedge \mathrm{J} 4)$ & $50^{0}$ & $\mathrm{~N} 76^{\circ} \mathrm{E}$ & $\begin{array}{l}\text { Possible wedge on } \\
\text { the crown and left } \\
\text { wall }\end{array}$ \\
\hline $\mathrm{I} 3(\mathrm{~J} 2 \wedge \mathrm{J} 5)$ & $52^{0}$ & $\mathrm{~N} 68^{\circ} \mathrm{E}$ & $\begin{array}{l}\text { Possible wedge on } \\
\text { the crown and left } \\
\text { wall }\end{array}$ \\
\hline $\mathrm{I} 4(\mathrm{~J} 2 \wedge \mathrm{J} 6)$ & $44^{0}$ & $\mathrm{~S} 54^{0} \mathrm{E}$ & $\begin{array}{l}\text { Possible wedge on } \\
\text { the crown and left } \\
\text { wall }\end{array}$ \\
\hline $\mathrm{I} 5(\mathrm{~J} 3 \wedge \mathrm{J} 4)$ & $52^{0}$ & $\mathrm{~N} 78^{\circ} \mathrm{E}$ & $\begin{array}{l}\text { Possible wedge on } \\
\text { the crown and left } \\
\text { wall }\end{array}$ \\
\hline $\mathrm{I} 6(\mathrm{~J} 3 \wedge \mathrm{J} 6)$ & $62^{0}$ & $\mathrm{~N} 70^{\circ} \mathrm{E}$ & $\begin{array}{l}\text { Possible wedge on } \\
\text { the crown and right } \\
\text { wall }\end{array}$ \\
\hline I7 (J4 ^ J6) & $48^{0}$ & $\mathrm{~S} 58^{0} \mathrm{E}$ & $\begin{array}{l}\text { Possible wedge on } \\
\text { the crown and left } \\
\text { wall }\end{array}$ \\
\hline $\mathrm{I} 8(\mathrm{~J} 4 \wedge \mathrm{J} 5)$ & $49^{0}$ & $\mathrm{~N} 66^{\circ} \mathrm{E}$ & $\begin{array}{l}\text { Possible wedge on } \\
\text { the crown and left } \\
\text { wall }\end{array}$ \\
\hline I9 (J5 ^ J6) & $78^{0}$ & $N 8^{0} \mathrm{E}$ & $\begin{array}{l}\text { Possible wedge on } \\
\text { the crown and right } \\
\text { wall }\end{array}$ \\
\hline
\end{tabular}

\section{B. Power house complex}

During the preliminary investigation of underground power house complex comprising of machine hall, transformer hall and downstream surge chamber, detailed surface mapping of the limited outcrop of rock mass was carried out on a scale of 1:1000 around the proposed cavern. Geotechnical parameters were collected for stability and wedge analysis of cavern. On the basis of analysis and interpretation of the outcrop joints, the tentative alignment of cavern was proposed as $\mathrm{N}^{0} \mathrm{~W}$ as plotted in Fig. 4.

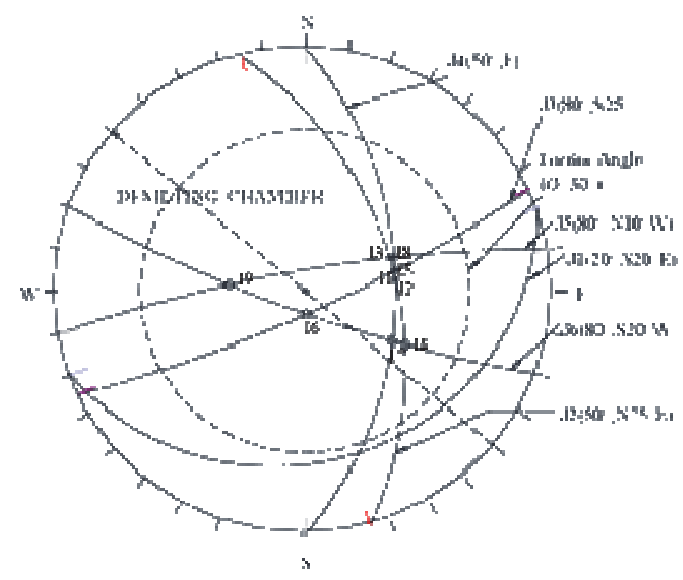

Fig 3. Stability analysis of wedges in desilting chambers

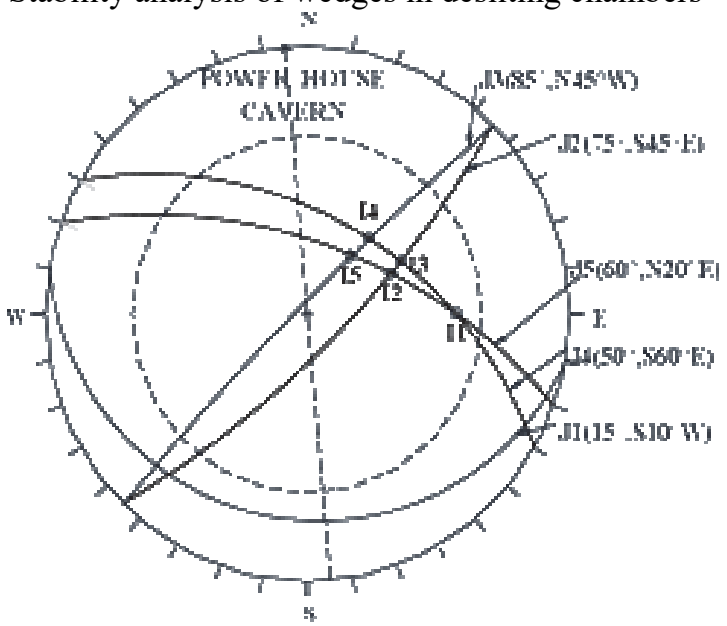

Fig. 4. Stability analysis of wedges in power house (Joints at outcrop)

Excavation of the adits started based on tentative alignment of underground caverns. The in-situ stresses were evaluated in adit to downstream surge chambers. The direction of maximum horizontal stress was worked out to be $\mathrm{N} 17^{0} \mathrm{E}$ which may be taken as stable orientation. Due to the difference in suitable orientation of cavern based on stress measurements $\left(\mathrm{N} 17^{\circ} \mathrm{E}\right)$ and wedge analysis $\left(\mathrm{N} 5^{\circ} \mathrm{W}-\right.$ outcrop of joints), all the joints inside the adit to downstream surge chamber were maped again. Variation in joint set properties with respect to the outcrop of joints was observed. Prominent sets of joints observed and recorded during excavation are summarised in Table IV. Stereo plotting of actual joints set data was carried out to finalise the most suitable orientation of the power house complex (Fig. 5). 


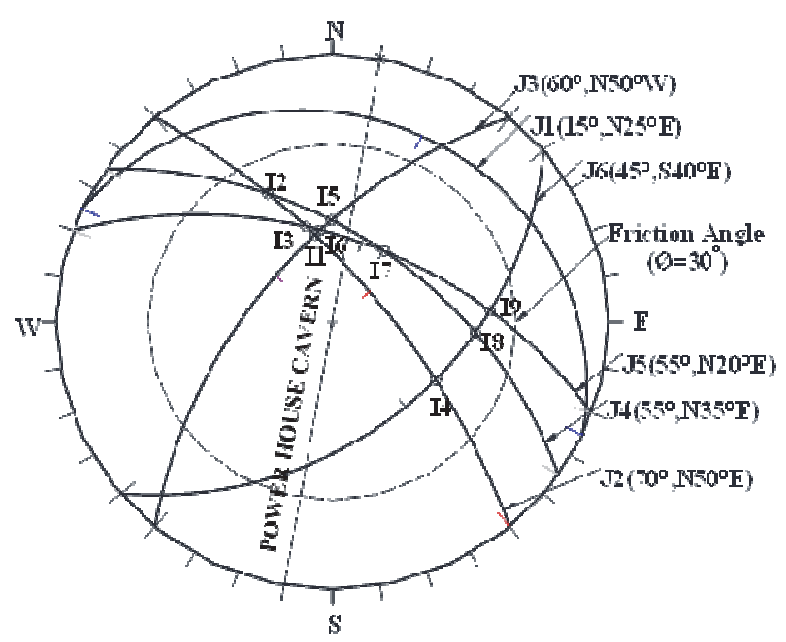

Fig 5. Stability analysis of wedges in power house cavern (Joints inside the cavern)

TABLE IV. DETAILS OF JOINT SETS IN POWER HOUSE COMPLEX

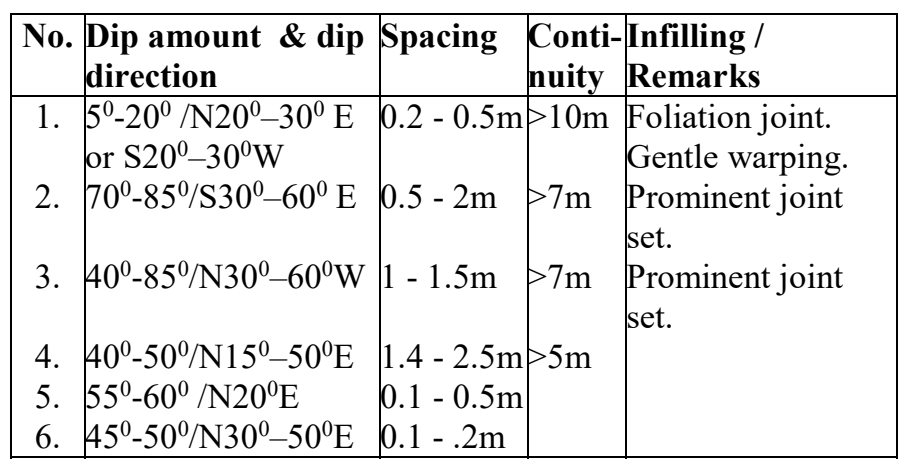

On the basis of wedge analysis (Fig. 5), the most favourable orientation of the long axis of the power house complex worked out to be $\mathrm{N} 10^{\circ} \mathrm{E}-\mathrm{S} 10^{\circ} \mathrm{W}$. The vulnerable wedges on the wall as well as on the crown of the gallery formed by intersection of joint sets have been tentatively delineated assuming angle of friction $(\varphi)$ of the rock joints as $30^{\circ}$ (Table V).

\section{ANALYSIS AND INTERPRETATION}

In the present case, the tentative orientation of the underground desilting chamber cavities worked out to be $\mathrm{N} 50^{\circ} \mathrm{W}-\mathrm{S} 50^{\circ} \mathrm{E}$ on the basis of surface mapping of the joints. The joint sets data seen as outcrop and inside the adit were almost matching.

In-situ stress measurements carried out in the desilting chamber drift indicated the direction of maximum horizontal stress as $N 49^{\circ} \mathrm{W}$. Since, the suitable orientation of the desilting chambers by both the criteria was matching; desilting chambers were finally aligned in $\mathrm{N} 50^{\circ} \mathrm{W}-\mathrm{S} 50^{\circ} \mathrm{E}$ direction.

Based on outcrop of major joint sets, long axis of power house complex was tentatively proposed in $\mathrm{N} 5^{\circ} \mathrm{W}-\mathrm{S} 5^{\circ} \mathrm{E}$ direction which is almost perpendicular to the ridge line (east-west trending) of the hill situated in between right bank of Punatsangchhu river and the left bank of Kamechu nala.

TABLE V. VULNERABLE WEDGES IN POWER HOUSE COMPLEX

\begin{tabular}{|l|l|l|l|}
\hline $\begin{array}{l}\text { Line of } \\
\text { intersection }\end{array}$ & $\begin{array}{l}\text { Plunge } \\
\text { amount }\end{array}$ & $\begin{array}{l}\text { Plunge } \\
\text { direction }\end{array}$ & Remarks \\
\hline I1 (J2 $\Lambda \mathrm{J} 3)$ & $52^{0}$ & $\mathrm{~N} 10^{0} \mathrm{~W}$ & $\begin{array}{l}\text { Possible wedge on } \\
\text { the crown and } \\
\text { right wall }\end{array}$ \\
\hline $\mathrm{I} 2(\mathrm{~J} 2 \wedge \mathrm{J} 4)$ & $44^{0}$ & $\mathrm{~N} 18^{0} \mathrm{~W}$ & $\begin{array}{l}\text { Possible wedge on } \\
\text { the right wall }\end{array}$ \\
\hline $\mathrm{I} 3(\mathrm{~J} 2 \wedge \mathrm{J} 5)$ & $50^{0}$ & $\mathrm{~N} 14^{0} \mathrm{E}$ & $\begin{array}{l}\text { Possible wedge on } \\
\text { the crown and } \\
\text { right wall }\end{array}$ \\
\hline $\mathrm{I} 4(\mathrm{~J} 2 \wedge \mathrm{J} 6)$ & $42^{0}$ & $\mathrm{~S} 60^{0} \mathrm{E}$ & $\begin{array}{l}\text { Possible wedge on } \\
\text { the left wall }\end{array}$ \\
\hline $\mathrm{I5}(\mathrm{J} 3 \wedge \mathrm{J} 4)$ & $50^{0}$ & $\mathrm{~N} 4^{0} \mathrm{~W}$ & $\begin{array}{l}\text { Possible wedge on } \\
\text { the crown and } \\
\text { right wall }\end{array}$ \\
\hline $\mathrm{I} 6(\mathrm{~J} 3 \wedge \mathrm{J} 6)$ & $52^{0}$ & $\mathrm{~N} 8^{0} \mathrm{~W}$ & $\begin{array}{l}\text { Possible wedge on } \\
\text { the crown and } \\
\text { right wall }\end{array}$ \\
\hline $\mathrm{I} 7(\mathrm{~J} 4 \wedge \mathrm{J} 6)$ & $54^{0}$ & $\mathrm{~N} 22^{0} \mathrm{E}$ & $\begin{array}{l}\text { Possible wedge on } \\
\text { the crown and left } \\
\text { wall }\end{array}$ \\
\hline $\mathrm{I} 8(\mathrm{~J} 4 \wedge \mathrm{J} 5)$ & $38^{0}$ & $\mathrm{~S} 70^{0} \mathrm{E}$ & $\begin{array}{l}\text { Possible wedge on } \\
\text { the left wall }\end{array}$ \\
\hline
\end{tabular}

Maximum horizontal stress direction from stress measurements was found to be $N 17^{0} \mathrm{E}-\mathrm{S} 17^{0} \mathrm{~W}$ and as per stresses criteria, power house complex should favourably be oriented in this direction. Hence, in view of difference in orientation based on stress measurement and wedge analysis of joints at the out crop, it was decided to map all the joints inside the adit to downstream surge chamber. Wedge analysis of actual joint set data indicated favourable orientation of the complex as $\mathrm{N} 10^{\circ} \mathrm{E}-\mathrm{S} 10^{\circ} \mathrm{W}$. Thus, the variation in suitable orientation of cavern was noticed with regard to outcrop of joints, actual joint sets and principal stress direction.

Due to low horizontal stresses of the order of 2.99 to 4.02 $\mathrm{MPa}$ in the power house complex attributed to isolated ridge, orientation was optimised giving due weightage to rock joints. Hence, based on the stress measurements and wedge analysis, the final orientation of power house complex was optimised as $\mathrm{N} 10^{0} \mathrm{E}-\mathrm{S} 10^{\circ} \mathrm{W}$.

\section{CONCLUSIONS}

Based on the study, the following conclusions are drawn: The stability of the underground structure is utmost important which largely depends on the in-situ stresses and the extent of discontinuities. The orientation of the underground opening may be kept more or less along the direction of major horizontal stress. However, the structure should also be checked against the instabilities resulting out 
of discontinuities likely to form vulnerable wedges. The final orientation of the underground opening should satisfy both the criteria. Numerical modelling tools may also be used to substantiate the final orientation. In case of conflict between optimal orientation based on principal stress direction and joint set orientation, each individual case must be decided on relative importance of the two parameters.

Wedge analysis of joints seen at the outcrop is not sufficient for deciding the orientation of large caverns. Hence, the wedge analysis of joint sets encountered inside the cavern is essential. The joint sets at outcrop were different than inside the adit to downstream surge chamber due to folding and faulting in the rock mass and topography of the hill.

\section{REFERENCES}

[1] Heim A. 1878. Untersuchungen über den Mechanismus der Gebirgsbildung. 2 vols, Basel.

[2] Terzaghi K. and Richart F.E. 1952. Stresses in rock about cavities. Geotechnique 3, 57-90.

[3] Wegener Alfred 1915. The Origin of Continents and Oceans. Book published in 1915.

[4] Hast N. 1958. The measurement of rock pressure in mines. Sver. Geol. Under. Ser. C. 52: 1-152.

[5] Dewey J.F. 1972. Plate tectonics. Scientific American, 226, 56-68.

[6] Mckenzie D.P. and Sclater J.C. 1973. The evolution of the Indian Ocean. Sci. Amer. 228(5): 63-72.

[7] Courtillot V. and G.E. Vink 1983. How continents breakup. Sci. Am., 249, $42-49$.

[8] Brown E.T. and Hoek E. 1978. Trends in relation-ships between measured rock in situ stresses and depth. Int. J. Rock Mech. Min. Sci. \& Geomech. Abstr. 15, pp.211-215.

[9] Herget G. 1988. Stresses in rock. Rotterdam: Balkema.

[10] Zoback, M. L. 1992. Stress field constraints on intraplate seismicity in eastern North America. J. Geophys. Res. 97, 11761-11782.

[11] Hoek E. 1977. Structurally controlled instability in underground excavations. Proc. 19th Rock Mechanics Symposium, Keystone, Colorado.

[12] Croney P., Legge, T.F. and Dhalla, A. 1978. Location of block release mechanisms in tunnels from geological data and the design of associated support. Computer Methods in Tunnels Design. The Institution of Civil Engineers, London, pages 97-119.

[13] Sheorey P.R. 1994. A theory for in situ stresses in isotropic and transversely isotropic rock. Int. J. Rock Mech. Min. Sci. \& Geomech. Abstr. 31(1), 23-34.

[14] Hari Dev, Rajbal Singh and Santosh K. Sati 2013. Orientation of Large Underground Caverns based on In-Situ Stresses and Wedge Analysis. Indorock-2013: Fifth Indian Rock Conference, 29-31 May 2013, Solan, India.

[15] Haimson B.C. and Fairhurst C. 1967. Initiation and extension of hydraulic fractures in rocks. Society of Petroleum Engineers Journal, Sept. PP 310-318.

[16] ISRM 1981. International Society for Rock Mechanics (ISRM) suggested methods for rock characterization, testing and monitoring. Editor: E.T. Brown, Published by Pergamon press, pp. 1-211.

[17] CSMRS 2012. Report on Hydrofracturing tests in Desilting Chamber of Punatsangchhu-II H.E. Project, Bhutan. June 2013.

[18] CSMRS 2013. Report on Hydrofracturing tests in Downstream Surge Chamber of Punatsangchhu-II H.E. Project, Bhutan. March 2013. 